\title{
KONSEP DASAR EKONOMI ISLAM DITENGAH KONSERVATISME PEMIKIRAN EKONOMI MODERN DI INDONESIA
}

\author{
Abu Bakar \\ Sekolah Tinggi Ilmu Syariah (STIS) AL-Ittihad Bima \\ Email: abubakar.dosen@gmail.com
}

\begin{abstract}
Abstrak
Konsep ekonomi Islam berbeda dan tidak mengadopsi sistim kapitalisme Barat maupun sosialisme. Sistem ekonomi Islam berbeda dari kapitalisme, sosialisme maupun negara kesejahteraan (welfare state). Walaupun disejajarkan dengan konsep sosialisme, Islam berbeda dalam hal kekuasaan negara, yang dalam sosialisme sangat kuat dan menentukan. Kebebasan perorangan yang dinilai tinggi dalam Islam jelas bertentangan dengan ajaran sosialisme. Meski demikian gagasan ekonomi kesejahteraan (welfare state) yang berada di tengah-tengah antara kapitalisme dan sosialisme memang lebih dekat ke ajaran Islam. Bedanya bahwa dalam Islam etika dijadikan pedoman perilaku ekonomi sedangkan dalam welfare state tidak demikian, karena etika welfare state adalah sekuler yang tidak mengarahkan pada "integrasi vertikal" antara aspirasi materi dan spiritual. Hal ini dapat dipahami melalui nilai-nilai dasar yang mengilhami ekonomi Islam di antara; konsep tauhid, rububiyyah, khalifah, dan tazkiyyah sebagi benyuk manifestasi nilai dasar ajaran Islam.
\end{abstract}

Kata Kunci: Ekonomi Islam, Pemikiran, Moderenisasi

\section{Pendahuluan}

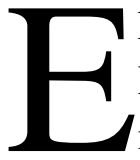

konomi Islam memiliki sifat dasar sebagai ekonomi rabbani dan insani. Dikatakan ekonomi Rabbani karena Islam sarat dengan tujuan dan nilainilai Ilahiyah. Sedangkan ekonomi Islam memiliki dasar sebagai ekonomi Insani, karena ssstem ekonmi Islam dilaksankan dan ditujuhkan untuk kemaslahatan manusia. Hal ini dapat dipahami melalui nilai-nilai dasar yang mengilhami ekonomi Islam, antara lain; konsep tauhid, rububiyyah, khalifah, dan tazkiyyah. ${ }^{1}$ Max Weber dalam bukunya the protestant ethic and the spirit of capitalism berpendapat ada hubungan erat antara agama dan etika kerja, atau antara penerapan ajaran agama dengan pembangunan ekonomi. Weber memang mulai dengan analis ajaran agama Protestan dan Katolik, disamping itu juga mulai banyak dibahas pengaruh-pengaruh agama lain seperti pengaruh agama Taoisme dan Confucianisme, Hindu dan Budha dan Yudaisme. ${ }^{2}$ Kuntowijoyo pernah berspekulasi dengan membuat sebuah hipotesis yang dilandasai dari pemikiran Max Weber di atas, bila etika Protestan melahirkan Kapitalisme tentunya etika Islam akan melahirkan Sosialisme. Tentu hipotesis ini telah banyak disanggah

\footnotetext{
${ }^{1}$ Kurshid Ahmad, Economic Development The Concept and Its Goals In Muslim, The Islam Fondation, (Malaya December-Marc 1997), 78-79.

${ }^{2}$ Max Weber, The Protestant Ethics and the Spirit of Capitalism, Charles Scribner"s Sons, (New York. 1958), 23-24.
} 
dengan berbagai ragam teori dan pendekatan yang akan mengelaborasi dan mensintesiskan antara ajaran-ajaran Islam dengan ekonomi.

Ilmu ekonomi meskipun secara empiris merupakan ilmu pengetahuan yang menggunakan kaidah dan metodologi ilmiah namun sebagai rumpun ilmu social tentunya tidak bebas nilai. Hasil dari penelitian Max Webertersebut meskipun kontennya masih terus dapat diperdebatkan tetapi substansinya sangat jelas bahwa ilmuilmu sosial termasuk ilmu ekonomi tidak bebas nilai.Lalu bagaimana nilainilai Islam dapat mempengaruhi etika kerja dan secara keseluruhan mempengaruhi pembangunan ekonomi. ${ }^{3}$ Dan tentunya hal yang menarik disini dan jarang disinggung adalah kenyataan budaya bahwa penerapan ekonomi Islam sebagai bagian ibadah muamalah belum menemukan bentuknya yang baku. Implementasinya di setiap negara-negara muslim. Beda budaya beda pula penerapan dan penurunan atau gradasi nilai-nilai Islam dalamekonomi. Prinsip dasar Islam yang terangkum dalam ajaran aqidah tentu semua sama namun bila sudah bersinggungan dalam level muamalah misalnya maka syariah Islam bisa menjadi lentur. Islam hanya mengatur dasar-dasar muamalah sedangkan implimentasi dalam kehidupan sehari-hari sangat tergantung juga dengan pengaruh budaya di masing-masing negara. ${ }^{4}$

Kembali kepada pokok permasalahan tersebut di atas bila penerapan nilainilai Islam dalam perspektif budaya dapat bersinggungan dengan nilai-nilai budaya setempat dan saling mempengaruhi. Dalam banyak hal Islam selalu memperkuat nilai-nilai budaya setempat, misalnya nilai budaya gotong-royong yang bertemu dengan nilai Ukhuwah Islamiyah dan menjadi bagian nilai baru yang sekilas meskipun secara eksplisit tidak memunculkan slogan Islam namun secara implisit muatan nilai-nilai Islamnya dapat ditelusuri dengan jelas. ${ }^{5}$ Sebagai contoh dalam bidang ekonomi, bisa jadi konsep-konsep ekonomi yang pernah digagas oleh para founding father Indonesia misalnya konsep ekonomi koperasi merupakan bentuk khas ekonomi Islam dalam konteks ke kiinianan. Sebuah paham agama atau ideologi lintas negara akan selalu berinteraksi denganbudaya

${ }^{3}$ Ekonomi Islam dikatakan sebagai sains social, Karen ailmu ekonomi mempelajari kehidupan manusia bermasyarakat ( termasuk ilmu sosialogi dalam arti yang terbtas). Lihat Manan, Islamics Economic Theory and Practice, (Idarat adabiyat, Delhi,1970), .3.

${ }^{4}$ Dalam kitab ini dijelaskan bahwa Islam terbagi kedalma Aqidah, Akhalak, dan Syariah, maka muamalat merupakan bahagian daripada syariah. Dalam hal muamalah ini beliau membagi kepada beberapa bahagian, yaitu : pelembagaan sivil, kekeluargaan, jenayah, hubungan antara bangsa, dan ekonomi keungan. Kitab Wahbah Al Zuhaili, al-fiqiah al-Islam wa Adillatuh, Dar Alfikr, Damsyiq Juz 2. 19.

${ }^{5}$ Kerja sama merupakan topik utama dalam pertumbuhan ekonomi sosial ekonomi Islam. Sikap individu dan kesadaran masyarakat terjalin secara erat dan bekerja untuk kesejahteraan orang lain dalam mencari rhido Allah. Lihat Monzer Kafh, The Islam Economic an analitycal Study of The Functioning of the Islamic Economic System. Muslim Students Association the United States and Canada, (Indiana 1997), 46-47. 
setempat. Dalam banyak hal implementasi dari interaksi paham atau ideologIi dengan budaya dan konteks setempat akan memunculkan revisi baru sebagai akibat dari penyesuaian-penyesuian. Revisi itu ada yang meninggalkan jauh paham atau ideology induknya tapi ada juga yang tidak. Landasan pemikiran yang sama juga dapat digunakan untuk merunut lahirnya paham atau ideologi komunisme di berbagai negara di era tahun 60-an hingga tahun 80-an, dimana ketika paham tersebut diterapkan pada negara yang berbeda maka penerapannya pun juga menjadi berbeda.

Komunisme versi Lenin sangat berbeda jauh dengan paham komunismenya Mao di Cina. Pada era lahirnya paham komunisme, di Eropa sangat dipengaruhi oleh revolusi industri, industri manufaktur tumbuh pesat di Eropa termasuk di Rusia, sehingga dalam perspektif ekonomi basis proletar komunisme di Eropa waktu itu adalah kaum buruh. Hal ini tentu berbeda dengankondisi di Cina dimana pertanian menjadi titik sentral pembangunan ekonomi di Cina waktu itu, sehingga basis kaum proletarnya tidak didominasi oleh kaum buruh tetapi oleh kaum petani. Penerapan komunisme era tahun 60-an di Indonesia pun menjadi lentur. Di era Presiden Soekarno paham komunisme mengalami revisi dan penyesuaian-penyesuian budaya.Sehingga dapat dikatakan bahwa ajaran sosialisme versi Marhaenisme itu merupakan revisi komunisme yang diajarkan Soekarno di Indonesia.

Berangkat dari alur pemikiran di atas maka timbul pertanyaan, apakah hal yang sama juga terjadi dalam perspektif Islam dalam ekonomi. Mungkinkan penerapan nilainilai Islam dalam ekonomi di setiap negara memiliki bentuknya masing-masing yang sangat tergantung dari budaya setempat. Apakah pemikiran ekonomi koperasi dan juga konomi Pancasila yang digagas Mubyarto dapat dikategorikan sebagai gagasan substansi nilai-nilai Islam yang sedang mengalami metamorphosis dalam konteks pembangunan ekonomi di Indonesia. Upaya-upaya pencarian gagasan segar tentang konsep ekonomi alternatif termasuk ekonomi Islam sangat relevan dengan situasi kekinian yang tengah dilanda kebuntuan sistim besar ekonomi kapitalis dan sosialis. Secara faktual ke dua sisitim tersebut tidak mampu membawa perkembangan ekonomi dunia keluar dari resesi yang berkepanjangan. Bahkah secara tegas dapat dikatakan bahwa kedua sistim tersebut telah gagal. Di tengah hegemoni kapitalistik Gidens menawarkan sebuah gagasan teori hegemoni yang berupa jalan ketiga the mid way dalam pengembangan ekonomi modern. ${ }^{6}$

\section{Hubungan Islam Dan Ekonomi}

Ilmu ekonomi Islam sebagai sebuah studi ilmu pengetahuan modern baru munculpada tahun 1970-an, namun sesungguhnya awal pemikiran Islam telah

\footnotetext{
${ }^{6}$ Gidens dalam Friedman Thomas, L, ( The World is Flat, 2005), 29-30.
} 
muncul sejak Islam itu diwahyukan melalui Nabi Muhammad SAW. Dalam catatan sejarah Islam, Nabi Muhammad mengawali praktik pembangunan ekonomi di kota Madinah mulai meletakkan dasar-dasar ekonomi yang mengacu pada nilai-nilai Islam terutama aqidah dan prinsip Tauhid. ${ }^{7}$

Hal ini dapat dilihat saat Rasulullah membangun ekonomi Madinah, beliau berusaha menerapkan prinsip keadilan dan kesetaraan agar terjadi redistribusi asset ekonomi diantara warga secara merata proporsional.Seperti diketahui dalam sejarah bahwa setelah hijrah kaum Muhajirin yang merupakan salah satupilar komunitas pembangun masyarakat Madinah secara ekonomi sangat marjinal. Hal ini bias dipahami karena kaum Muhajirin telah meninggalkan seluruh harta benda dan aset-aset ekonomi lainnya di kota Mekah. Maka pada saat itu persoalan pertama dalam ekonomi yang dihadapi Rasulullah adalah ketimpangan ekonomi social antara kaum Muhajirin (pendatang) dengan penduduk kota Madinah. Maka kalau dirunut dalam proses kesejarahaan konsep ekonomi pertama yang akan ditegakkan Rasulullah pada saat membangun kota Madinah adalah redistribusikekayaan, sehingga tidak terjadi ketimpangan ekonomi diantara elemen masyarakat penyangga kota Madinah. ${ }^{8}$

Strategi tersebut dilakukan Rasulullah dengan mempersaudarakan antara kaum Muhajirin dengan kaum Anshor. Piagam Madinah sebagai tonggak civil society dalam sejarah Islam sesungguhnya merupakan kebijakan yang dalam perspektif ekonomi agar redistribusi roda perekonomian di kota Madinah berjalan"...jangan sampai kekayaan hanya beredar dikalangan orang-orang kaya saja diantara kamu” (QS. 59:7). ' Seperti di ketahui bahwa selain kaum Muhajirin dan kaum Anshor di Medinah juga berrmukimmasyarakat dari suku bangsa lain semisal kaum Yahudi. Rasulullah mendorong agar semua komponen masyarakat melakukan kerjasama ekonomi sehingga roda perekonomian terus berputar. Konsep perdagangan dengan Sistim Mudharobah (profit and loss sharing) sudah diperkenalkan Rasulullah pada masa ini.Kelak kemudian hari para pemikir ekonomi Islam modern melandaskan pemikirannya pada Sistim Mudharobah sebagai antitesa dari sistim ekonomikonvensional. Pengaruh pribadi Rasulullah sebagai seorang saudagar tentunya turut andil dalam mempengaruhi gaya beliau dalam mengkonsep sebuah sistim ekonomi yang adil di kota Madinah. Maka dapat dikatakan bahwa sesungguhnya Islam dan ekonomi sudah merupakan bagian yang tak terpisahkan sejak awal lahirnya Islam.

Persoalan redistribusi kekayaan yang menjadi persoalan ekonomi pada awal Rasulullah membangun kota Madinah sesungguhnya juga merupakan sebuah

\footnotetext{
${ }^{7}$ Keadilan dan Kesejhateraan social merpakan tujuan dari system ekonomi Islam. Lihat Amin Akhtar, The Structur Framework Of The Economic System Of Islam (Karachi,1980),78-79.

${ }^{9}$ QS. An-Nisa/4: 134

10. QS. Al-A'raf/7: 59
} 
persoalan krusial dan mendasar yang dihadapi oleh semua paham ekonomi lainnya seperti sosialisme dan kapitalisme. Nilai keadilan dan kesetaraan dalam konsep perekonomian yang dijalankan Rasulullah tersebut misalnya dalam sistim profit and loss sharing atau mudarobah tidak bisa dilepaskan dari nilai-nilai Tauhid yang sedang di perjuangkan kaum muslimin pada masa itu. Seperti diketahui bahwa pada dasarnya, ilmu sosial termasuk didalamnya selalu diawali dan didasari pada nilai-nilai tertentu, baik aspek ontologism, epistimologis maupun aksiologis. ${ }^{10}$ Dengan demikian tidak ada ilmu ekonomi yang bebas nilai. Sehingga perlu kiranya mengetahui bahwa dalam ilmu ekonomi Islam dikenal dengan istilah ilmuekonomi normatif. Tidak semua hal dalam ekonomi berlaku positip yang menganggap semua fakta ekonomi merupakan sesuatu yang bersifat independen terhadap norma atau nilai-nilai tertentu. Sebagai contoh, hukum penawaran (supplay and demand) yang menyatakan bahwa jika harga suatu barang meningkat, maka jumlah barang yang ditawarkan akan meningkat, ceteris paribus, merupakan pernyataan positip. Hukum tersebut berlaku karena para produsen memandang bahwa kenaikkan harga barang adalah kenaikkan pendapatan mereka dan motivasi produsen adalah untuk mencetak keuntungan pendapatan sebanyak-banyaknya.

\section{Tinjau Prinsip Dasar Ekonomi Islam}

Menurut Khomaini bahwasannya konsep ekonomi Islam berbeda dan tidak mengadopsi sistim kapitalisme Barat maupun sosialisme. Sistem ekonomi Islam berbeda dari kapitalisme, sosialisme, maupun negara kesejahteraan (welfare state). Walaupun disejajarkan dengan konsep sosialisme, Islam berbeda dalam hal kekuasaan negara, yang dalam sosialisme sangat kuat dan menentukan. Kebebasan perorangan yang dinilai tinggi dalam Islam jelas bertentangan dengan ajaran sosialisme. Meski demikian gagasan ekonomi kesejahteraan (welfare state) yang berada di tengah-tengah antara kapitalisme dan sosialisme memang lebih dekat ke ajaran Islam. Bedanya hanyalah bahwa dalam Islam etika dijadikan pedoman perilaku ekonomi sedangkan dalam welfare state tidak demikian, karena etika welfare state adalah sekuler yang tidak mengarahkan pada "integrasi vertikal" antara aspirasi materi dan spiritual. Demikian dapat disimpulkan bahwa dalam Islam pemenuhan kebutuhan materiil dan spiritual benar-benar dijaga keseimbangannya, dan pengaturaan oleh Negara dan tidak akan bersifat otoriter. State intervention, directed primarily at reconciling the possible social conflict betweenman's ethical and economic behaviors cannot lead the society onto "road to serfdom"but will guide it gently along the road to human freedom and

\footnotetext{
${ }^{10}$ Keadilan dan Kesejhateraan Social Merpakan Tujuan Dari System Ekonomi Islam. Lihat Amin Akhtar, The Structur Framework Of The Economic System Of Islam, (Karachi, 1980),78-79.
} 
dignity. ${ }^{11}$ Selanjutnya terdapat empat prinsip utama yang dikedepankan dalam ekonomi Islam yaitu: Kesatuan (unity), Keseimbangan (equilibrium), Kebebasan (free will). dan Tanggungjawab (responsibility).

Prinsip-prinsip tersebut, kemudian dikembangkan lagi menjadi prinsip equal opportunity atau pemerataan dalam kesempatan. Sampai saat ini belum dapat dipastikan bahwa ada negara yang mengadopsi penuh paham Ekonomi Islam secara menyeluruh. Kesejahteraan ekonomi yangditunjukkan oleh negaranegara Timur Tengah seperti Arab Saudi, Qatar, UEA dan lain lain masih diragukan terkait implementasi dari penerapan Ekonomi Islam. Negara-negara tersebut bahkan mungkin dapat dikatakan merupakan sebagai "boneka" ekonomi kapitalisme Barat yang hendak dipertahankan untuk membendung penerapan nilai Islam berkembang dan menemukan identitasnya dalam ekonomi. ${ }^{12}$ Hal ini tentu saja sangat ironi mengingat Timur Tengah justru merupakan pusat lahirnya Agama Islam. Mungkin kalau boleh jujur, Negara Islam Iran bisa dikatakan merupakan model yang mendekati Sistim Ekonomi Islam meskipun hal ini juga masih dapat diperdebatkan juga. Nilai-nilai kepemimpinan dalam Mahzab Syi'ah sangat kental mempengaruhi paham ekonomi negara tersebut. Meski secara idiologi mahzab Syi'ah sendiri masih sangat kontroversial, namun ada beberapa prestasi yang patut di catat di negeri ini, bahwa Iran merupakan Negara di Asia yang nyaris tidak terjerat hutang luar negeri dan Lembaga Moneter Dunia seperti IMF dan Bank Dunia, tingkat pendapatan perkapita penduduknya relatif tinggi dan tidak ada kesenjangan ekonomi. Meskipun negeri ini diembargo perdagangan internasional tetapi roda pertumbuhan ekonominya bisa dikatakan stabiljustru ketika dunia sedang mengalami resesi.T entu saja hal ini sedikit banyak merupakan pengaruh dari nilai-nilai Islam yang secara resmi dijadikan landasan idiologi untuk mengatur negara secara keseluruhan termasuk dalam mengatur perekonomian negaranya.

\section{Jalan Tengah (The Midof Way) Dalam Pengembangan Ekonomi}

Era globalisasi dengan sistem pasar bebas menjadikan setiap roda perekonomian dikelola dengan prinsip ekonomi yang rasional dan tidak manusiawi. Dengan alasan efektivitas, efisiensi, dan produktivitas, pasar bebas mengabaikan pemihakan pada pelaku ekonomi lemah. Prinsip-prinsip tersebut hanya bermuara pada pengabdian kepada keuntungan belaka.Siapa yang kuat itu yang menang, menjadi slogan dari pasar bebas. Di saat itulah perdagangan bebas

\footnotetext{
${ }^{11}$ Mubyarto, Membangun Sistem Ekonomi (Yogyakarta: BPFE, 2000), 81

${ }^{12}$ Dalam IslamPrinsip-prinsip Kesatuan (unity), Keseimbangan (equilibrium), Kebebasan (free will). dan Tanggungjawab (responsibility).sangat diperhatikan dan sangat fundamental dalam pandangan Ekonomi Islam. Lihat Safi'i Anwar, Alternativ Terhadap Sistem Riba ( Jurnal Ulumul Quran, 1991), 10-41.
} 
berhadap-hadapan dengan nilai-nilai kemanusiaan dan keberpihakan. ${ }^{13}$ Selama ini seakan tidak ada pilihan lagi bagi perekmbangan ekonomi dunia. Saat ini sistim perekonomian bangsa berkutat pada perdebatan dua model pendekatan: (1) pendekatan kapitalis yang memandang modal finansial sebagai factor utama dalam pertumbuhan ekonomi. (2) pendekatan manusia, yang memandang sumberdaya manusia yang menjadi faktor utama dalam pembangunnan ekonomi.kedua pendekatan itu telah dilakukan. yang pertama oleh negara-negara liberalkapitalis di Eropa, sedangkan pendekatan kedua dilaksanakan oleh negaranegara sosialis.

Pendekatan- pendekatan tadi memiliki kekuatan dan kelemahan. Kekuatan pendekatan pertama yang bertolak dari kepemilikan modal menjadikan perekonomian suatu negara bisa berkembang cepat dengan pertumbuhan yang tinggi. Sekalipun demikian, pendekatan kapitalis tersebut menimbulkan dampak negatif antara lain : Pertama, karena terjadinya eksplotasi dan marginalisasi tenaga kerja yang menciptakan pengangguran dan kemiskinan. Kedua, sering menimbulkan kelebihan produksi dan jatuhnya harga barang-barang. Ketiga terjadi siklus bisnis yang berulang ulang, keempat, terciptannya konsentrasi kekuatan ekonomi dan kesenjangan sosial-ekonomi di tingkat nasional dan internasional. Keempat, terjadinya eksploitasi dan monopoli oleh yang kuat kepada yang lemah dan kerusakan lingkungan hidup serta terancamnya kelestarian sumberdaya alam. sistem kapitalis-liberal juga menimbulkan krisis finansial global dan resesi perekonomian dunia, seperti yang akhir-akhir ini terjadi.

Sementara itu sistim sosialis pada umumnya proses perkembangan ekonomi itutidak didasarkan oleh motivasi individu maupun kelompok, melainkan dengan caramobilisasi dari atas, sehingga timbul dua gejala yang pertama, proses eksploitasi terhadap sumberdaya manusia. Sedangkan yang kedua, tingkat pendapatan masyarakat rendah, daya beli rendah dan tidak terbangunnya pasar yang luas.dengan demikian, hukum yang mengatakan bahwa penawaran akan menciptakan permintaan sendiri tidak terjadi. Selain itu,sebagai hasil ekploitasi terhadap sumberdaya manusia justru Negara dan bukannya masyarakat yang bisa memperoleh penerimaan yang besar. Penerimaan negara itu kemudian menimbulkan akumulasi kapital sebagai sumber investasi negara, yang kemudian dipakai untuk membiyai pemerintahan sipil maupun militer. ${ }^{14}$

Perkembangan ekonomi dunia telah berhenti pada dua pendekatan ini, sehingga Anthony Giddens dalam teori Hegemoninya menyebutkan perlunya jalan ketiga "the mid way" sebagai jalan alternatif. Maka dalam wacana ini Islam

${ }^{13}$ Ahmad Zainal Abidin, Dasar-dasar Ekonomi Islam (Jakarta: Bulan- Bintang, 1997),1213.

${ }^{14}$ Kohar, Mudzakar, Abdul. Ekonomi Islam: Suatu Perbandingan Pandangan Dan Sejarah Pemikiran, (Bogor: PPS IPB, 2005), 53. 
diletakan dalambingkai jalan tengah dari kedua pendekatan ini. Gagasan Anthony Gidden tersebut sangat asuk akal mengingat secara factual ekonomi global sedang berjalan menuju kebangkrutan dengan ditandai olehkegagalan ke dua jalan pendekatan diatas yaitu kapitalis dan sosialis.Namun Giddens tidak merinci secara tegas jalan ketiga itu sebagai sebuah paradigma yang utuh. Beberapa eksperimen lokal yang mencoba keluar dari hegemoni dua pendekatan tersebut sudah dapat dikatakan sebagai model pendekatan ketiga.

Dalam perspektif tersebut Islam sebagai sebuah sistim dapat dikategorikansebagai kekuatan ke-3 (tiga) yang diharapkan dapat membawa angin segar perubahan. Namun terdapat kendala dimana saat ini phobia terhadap Islam di kalangan barat masih menjadi kendala besar bagi sistim Islam untuk tumbuh berkembang secara alami sebagai paradigma ekonomi jalan ketiga. Di Indonesia sendiri di era penjajahan (tahun 1940-an) phobia terhadap Islam benihnya sudah ditanam oleh bangsa Belanda. Ide-ide atau gagasan besar yang membawa sistim Islam khususnya dalam bidang ekonomi bagi kaum intelektual saat itu kurang begitu diminati karena stereotip-stereotip negatif yang diarahkan secara membabi buta pada Islam. Selanjutnya Anthony Giddens dalam teori Hegemoninya menyebutkan koperasisebagai "the mid way" atau "jalan tengah" untuk melawan dan menandingi atau paling tidak sebagai penyeimbang dalam menghadapi hegemoni ekonomi kapitalistik. ${ }^{15}$

Dalam realitanya, perkembangan lahirnya koperasi dilandasi sebagai sebuah bentukperlawanan hegemoni kekuatan kapitalistik dan imperialisme penjajahan Belanda kepadabangsa Indonesia. Meskipun mayoritas penggagas koperasi adalah kaum muslimintelektual saat itu namun dalam praktiknya nilainilai Islam tidak muncul secaraeksplisit dalam pergerakan koperasi tersebut. Ideide ekonomi dalam koperasi secarasubstansif mengarah pada redestribusi asset ekonomi agar merata diseluruh anggotaanggotanya. Sisa Hasil Usaha (SHU) yang dibagi secara merata diantara anggota-angotakoperasi merupaka implementasi dari konsep redestribusi agar asset ekonomi tidakberputar dikalangan orang-orang kaya tertentu saja. Hal ini sesuai dengan jiwa dan nilai Islam “..jangan sampai kekayaan hanya beredar dikalangan orang-orang kaya sajadiantara kamu..." (QS. A'raf/7: 59). ${ }^{16}$ Secara implisit sistim kelola ekonomi seperti koperasi ini merupakan ruh ekonomi yang pernah diterapkan Rasulullah ketika melakukan pembangunan ekonomi di kota Madinah. Namun apakah model ekonomi koperasi sebangun dengan model ekonomi Islam perlu dikaji lebih jauh lagi. Sehingga dalam wacana ini dimunculkan sebuah tesis bahwa ekonomi koperasi merupakan

\footnotetext{
${ }^{15}$ Mac Donald, V.N. and P.J. Lawton., Improving Manajemen Perform: The Contribusi of Productivity and Performance Measuremant.(Local Government Project. Series Publications Technical Papers. 1977).

${ }^{16}$ Q.S. $7: 59$
} 
metamorphosis dari ekonomi Islam dalam konteks ke-Indonesia-an. Banyak sekali muatan nilai-nilai lokal dalam koperasi seperti nilai gotong royong merupakan ruh dari nilai Islam juga yaitu ukhuwah yang secara bebas bisa disejajarkan dengan nilai gotong royong. Namun demikian apakah koperasi ini merupakan pengaruh langsung dari sebuah penerapan nilai-nilai seperti dalam konteks penelitian Max Weber. ${ }^{17}$ Perlu kiranya diuji secara empiris dimasa mendatang. Untuk lebih memberi gambaran tentang sejarah perkoperasian di Indonesia berikut ini dipaparkan secara sekilas.

Pertumbuhan koperasi di Indonesia dipelopori oleh R. Aria Wiriatmadja (1896). ${ }^{18}$ Mendirikan koperasi simpan pinjam. Selanjutnya Boedi Oetomo dan Sarekat Islam menganjurkan berdirinya koperasi untuk keperluan rumah tangga. Sarekat Islam lebih konkret lagi mengembangkan koperasi yang bergerak di bidang keperluan sehari-hari dengan cara membuka took koperasi. Berkembang pula di awal-awal koperasi Syirkatul Inan milik NU tahun 1918 di Jombang. Kegiatan serupa juga dilakukan oleh Partai Nasional Indonesia di bawah pimpimnan Ir. Soekarno, di mana berdasarkan keputusan kongres 1929 bahwa untuk meningkatkan kemakmuran penduduk BumiPutera harus didirikan berbagai macam koperasi di seluruh Pulau Jawa khususnya dan di Indonesia pada umumnya. Selanjutnya pada Kongres Muhamadiyah pada tahun 1935 dan 1938 memutuskan tekadnya untuk mengembangkan koperasi di seluruh wilayah Indonesia, terutama di lingkungan warganya. Berbagai koperasi dibidang produksi mulai tumbuh dan berkembang antara lain koperasi batik yang diperlopori oleh $\mathrm{H}$. Zarkasi, H. Samanhudi dan KH. Idris. Pengembangan koperasi sendiri bisa dikatakan menggunakan pendekatan ke 3 (tiga) karena sistim ini sifat-sifatnya tidak sama dengan sistim kapitalis namun demikian meski mengusung konsep gotongroyong dan kebersamaan koperasi bukan merupakan gagasan yang lahir dari sosialisme.

Ekonomi koperasi sendiri merupakan implementasi dari amanah konstitusi yaituUUD 1945. Perlu diketahui bahwa pada awalnya gagasan mukadimah dari konstitusiUUD 1945 secara eksplisit memasukkan unsur syari'ah Islam yang berbunyi :menjalankan syariat Islam bagi pemeluknya masing-masing, ini artinya bahwasemangat nilai-nilai Islam sudah muncul sejak founding father menggagas bentukNegara Indonesia ke depan termasuk dalam konsep pembangunan ekonominya. Namun setelah mengalami kompromi maka naskah asli dari mukadimah UUD 1945 yang dikenal sebagai Piagam Jakarta itu dihilangkan sehingga teks mukadimah dari UUD 1945 menjadi seperti dalam bentuknya yang

\footnotetext{
${ }^{17}$ Weber, Max. The Protestant Ethics and the Spirit of Capitalism, Charles Scribner"s Sons New York, 1958). 31-32.

${ }^{18}$ R. Aria Wiriatmadja, Menggagas Ilmu Ekonomi Islam, (Cet. 3; Yogyakarta : Pustaka Pelajar, 2003).44-45.
} 
sekarang. Meskipun kata syariah telah dihilangkan dari mukadimah UUD 1945, namun jiwa Islam masih sangat lekat dalam seluruh bangunan konstitusi tersebut tidak ada perubahan yang signifikan dalam pasalpasalnya.

Dibentuknya koperasi-koperasi primer yang berbasis sector riil pertanian maupunperdagangan merupakan bentuk mekanisme pertahanan untuk memerangi riba seperti gharar atau spekulasi, monopoli yang merugikan dan bentuk-bentuk riba yang lain. Sesungguhnya koperasi merupakan salah satu pilar untuk menegakakan dua hal yaitu menjamin kebutuhan dasar bagi masyarakat dan pemerataan distribusi pendapatan dan kekayaan. Sedangkan pilar lainnya adalah pemerintahan (daulah) yang secara sinergi seharusnya memiliki tugas yaitu mengarahkan perkembangan ekonomi nasional akanterus mengerah pada kepentingan dan kemakmuran rakyat dan mengambil berbagai kebijakan ekonomi dan non ekonomi yang relevan bagi perwujudan falah atau kemuliaan masyarakatnya. Sinergi ini merupakan bangunan cita-cita yang hendak diimplementasikan dalam konsep ekonomi Islam. Dan pernah diterapkan oleh Rasulullah ketika melakukan pembangunan ekonomi di Kota Madinah. ${ }^{19}$

\section{Penutup}

Ilmu ekonomi meskipun secara empiris merupakan ilmu pengetahuan yangmenggunakan kaidah dan metodologi ilmiah namun sebagai rumpun ilmu social tentunya ilmu ekonomi tidak bebas nilai.Agama dan kearifan budaya dapat menjadi sumber nilai-nilai yang mempengaruhi bentuk dan praktik ekonomi di masyarakat. Disisi lain penerapan ekonomi Islam dalam perspektif budaya bersinggungan dengan budaya setempat membentuk pola yang saling mempengaruhi. Konsep-konsep ekonomi yang pernah digagas oleh para founding father di Indonesia misalnya tentang ekonomi koperasi dapat dikatakan sebagai metamorphosis ekonomi Islam dalam konteks ke Indonesia-an. Dibentuknya koperasi-koperasi primer yang berbasis sektor riil pertanian maupun perdagangan merupakan bentuk mekanisme pertahanan untuk memerangi riba dan sikap monopoli yang merugikan serta bentuk riba yang lain. Konsep dan gagasan ini sesungguhnya bertentangan dengan konsep dan gagasan ekonomi Islam. Dalam konteks inilah Gidens dalam Friedman Thomas, menyebut koperasi dapat dikatagorikan sebagai "the mid way"atau "jalan tengah" untuk melawan dan menandingi ataupaling tidak sebagai penyeimbang dalam menghadapi hegemoni ekonomi liberal-kapitalistik dalam kehidupan sosial masyarakat.

${ }^{19}$ Qaradhawi, Y. Kiat Islam Mengentaskan Kemiskinan. (Terjemahan). Penerbit Gema Insani Press, ( Jakarta.1995),19-20.Secara berlahan, tetapi pasti, system bisnis dan keuangan terus berkembang.Ia telah memasuki berbagai sector keuangan dan bisnis keuangan di Indonesia. Sekarang mulai berkembang pasar modal syariah, dimana Bursa Efek di Jakarta telah dikenal adanya Jakarta Islalamic Index (JII). Dibursa yang sama juga telah di introduksikan juga dan diperdagangkan produk atau instrument pasar modal berupa Reksa Dana Syariah dan Obligasi Syariah 


\section{DAFTAR PUSTAKA}

Departemen Agama RI. Al-Qur'an Al-Karim dan Terjemahanya, 2002.

Friedman Thomas, L, The World is Flat, 2005.

Hayati, Nur \& Wibowo, Ery. Kompetensi Sumber Daya Manusia Menuju Ekonomi Rakyat Berbasis Koperasi Indonesia. Proceeding: Semarang. 2011.

Khomaini, Ayatullah. Kepemilikan Swasta Dalam Islam, 2005.

Kohar, Mudzakar, Abdul. Ekonomi Islam: Suatu Perbandingan Pandangan Dan Sejarah Pemikiran. Bogor, PPS IPB, 2005.

Mac Donald, V.N. and P.J. Lawton. Improving Manajemen Perform: The Contribusi of Productivity and Performance Measuremant, 1977.

Mubyarto, 2000.Membangun Sistem Ekonomi. BPFE, Yogyakarta.

Mubyarto. Penerapan Ajaran Ekonomi Islam Di Indonesia. Yogyakarta: UGM, 2002.

P3EI. Ekonomi Islam. Jakarta: Raja Grafindo Persada, 2008.

Qaradhawi, Y. Kiat Islam Mengentaskan Kemiskinan.(Terjemahan).. Jakarta: Penerbit Gema Insani Press, 1995.

Scribner"s Sons, New York. 1958.

Weber, Max. The Protestant Ethics and the Spirit of Capitalism, Charles 